\title{
The life of a racehorse - 150 years ago and today
}

\author{
Hanspeter Meier \\ Urtenen-Schönbühl, Switzerland
}

\begin{abstract}
Summary: 'The Life Of A Racehorse' is the title of a booklet, published 1865 in London by John Mills. In 21 chapters on 112 pages, it embraces the fate of the fictitious racehorse Sheet Anchor. His recollection of a life fraught with sorrowful changes starts with the basic education and training, where a horse should not be blamed and punished for his natural sensitiveness. He nevertheless underwent these preparations without problems and developed into a successful two-year-old and the winner of the Derby. His success kindled the interest of the betting community and Sheet Anchors' fate turned. He became the victim of safe methods for the increase of betting returns by laying against him. He suffered defeats caused by ruthless tactics, broke down, was drugged and nobbled, was sold several times and ended after a raffle as the property of a cabman. At this stage he wondered whether leaving back in his birthplace would have been a fare more pleasing scene. Although the story of Sheet Anchor is presented as a novel, the gloomy pictures reflect the situation of racing in the first half of the 19th century reliably. At these times, racing in Great Britain is reported to have been at the lowest moral ebb of its history. The described methods of the education and training also are criticized elsewhere and even may still be encountered in our days. Deplorably, the same can be said in regard to some medical treatments of the racehorse. In the history of racing, betting obviously was a main reason for grievances, and these risks (or human frailties) also still have to be dealt with in our society. Fortunately, in regard to welfare-issues in the context with the retirement of racehorses, meanwhile true progress happened in different places. Today, there is a generally accepted understanding that the commitment to the care and well-being of a horse must come along with the thrill of owning it. In accordance with this, the promotion of welfare is considered a key requirement for the future viability of the racing industry.
\end{abstract}

Keywords: horse / racing / history / education / training / betting / injuries / welfare

Citation: Meier H. (2015) The life of a racehorse - 150 years ago and today. Pferdeheilkunde 31, 484-488

Correspondence: Dr. Hanspeter Meier, Baumgärtliweg 17, 3322 Urtenen-Schönbühl, Schweiz, E-mail: mail@hanspetermeier.ch

\section{The narrative}

'The Life Of A Racehorse' is the title of a booklet, published 1865 in London by John Mills, also the author of many further narratives, e.g. 'The Old English Gentleman', 'Flyers Of The Hunt', 'The Life Of A Foxhound' etc. It embraces the fate of the fictitious racehorse Sheet Anchor and is presented as a novel in the first person of this Thoroughbred. His memories start with the first months of his life as a foal by Made Safe out of Dangerous, herself by Fleece'em and out of Treachery by Nobbler, said to be untainted blood of Godolphin for centuries. He was named 'Sheet Anchor' ('Not-' or 'Rettungsan-

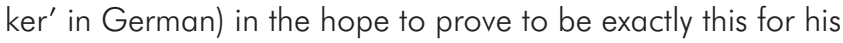
breeder and owner.

In 21 chapters on 112 pages, Sheet Anchor first remembers happily the earliest scenes with his dam, but afterwards it is a recollection of a life fraught with sorrowful changes. These start with his basic education, described in the chapter 'The Dumb Jockey', when he had a crossed piece of wood strapped on his back. Here he mentions that the frequently used expression 'bad temper', might be far more correctly traced to the innate apprehension of danger so predominant in the equine nervous system. He further expresses his feelings that one should not be blamed and consequently also ought not be punished for this natural sensitiveness. It also should be remembered that horses possess memories of a truly tenacious kind; and anything which has once proved a source of positive terror to them, they rarely forget, and, occasionally, never.

In his further training, Sheet Anchors' strength and spirits increased daily, but he also felt his temper becoming far more irritable. He therefore wonders that "there wouldn't be such a deal o' boltin', kickin' swervin', shyin', buckin', and break- downs, if people would give themselves the trouble o' finding out that a good deal o' temper, in men and 'osses, depends on the way in which they're humoured".

As a two-year-old, Sheet Anchors' work was gradually increased and he was set going at half speed. After his journey to Newmarket he also experienced his first sweat with an extra quantity of clothing and after this work-out, perspiration ran in streams down his legs and trickled away in currents from the fetlocks.

He had now undergone his first preparations, and, greatly to the delight of the trainer John Sellusall, no symptoms of curbs, sore shins, effusions in the legs, heat, or any of the innumerable and unfavourable signs of 'going through the sieve' presented themselves.

The maiden race was now the next goal in Sheet Anchors' career, the Criterion, which was run over 5 furlongs and 182 yards. He proved to be the easiest winner of these Stakes on record and immediately, a voice cried "I'll back him for the Derby", and another one replied "I'Il lay fifteen to one against him".

Sheet Anchor 'wintered well' and became one of the two leading favourites for the Derby. Watchful care was bestowed both night and day, and his box was constantly guarded, so that no one on desperate mischief bent might approach to injure him. In the race, Sheet Anchors' heart was in the effort, and success was his - he won by a neck.

Such was the meridian of Sheet Anchors' destiny and the next chapter is titled 'Fate's Table Is Turned'. However, he still can- 
tered in easily in the Ebor St. Leger, and this victory might have been the shadow of the still greater one to be contested for in the Doncaster St. Leger. But prior to this, Sheet Anchor overheard abstruse calculations upon the safe method to be adopted for the increase of betting returns, in the sense of "little fish were sweet enough when larger couldn't be caught". According to the trainer Sellusall and the jockey Ned, "the opportunity was great of making money. A hundred thousand might be won by laying against our horse - gently and tenderly managed - and backing his rival. A little, very little, will do the trick - rope him". Consequently the event was no longer a matter of uncertainty. They had resolved upon turning Sheet Anchors' predetermined loss to their own profit and insuring an advantage devoid of the smallest possible risk. In the race, Ned slipped his hands forward, and getting a short hold of his reins, threw his body back almost upon the quarter. The entire weight of his body, diminutive as it was, being thus thrown into the jaws. On the post itself, at the moment Sheet Anchor wanted but a slackened rein, the heartless devil on his back pulled him from his stride, and the race was - lost.

Within a little more than a week of the defeat of Sheet Anchor for the St. Leger, a public advertisement appeared: "To be sold at Tattersall's ... without reserve, the entire stud, ... the property of a gentleman retiring from the turf."

"Twenty-one hundred and fefty guineas are bid. Going, any more?" Down came the ivory hammer with a sharp crack upon the desk, and Sheet Anchor was sold to Slippery Mo. The new owner got he advice "Your 'oss can win anything; but like a woman, to see 'm shine the brightest, he must be tickled, not punished."

Unfortunately, the first impression of the new trainer's worldly condition proved too correct; Tom Shybird was poor, in doubtful credit, and under heavy pecuniary obligations to Slippery Mo. On the verge of bankruptcy he kept him there, knowing full well that, for some of his purposes to be served, there was nothing like a desperate man.

Sheet Anchors' new owner spoke of his breaking down in a selling stake as part of the contemplated scheme for getting him lightly weighted for some great handicap. But instead of being able to make certain of pulling off 'a good thing', Sheet Anchor already broke down in his next race. The inflammation in his leg was very great, and the veterinary surgeon at once commenced the task of reducing it, by bleeding him from the toe. Some three months afterwards, Sheet Anchor also had the straight lines of the cautery branded upon his leg. He was now thrown for months completely out of work - and that if he saw the post again within the year, it appeared barely possible that he should do so. His trainer therefore observed "It must be made worth my while to nobble him".

In the chapter 'The Drug', where Sheet Anchor 'had been got $\mathrm{at}^{\prime}$ ', he wondered whether to dwell longer upon his suffering. But the seizure made by the Sheriff was followed by a peremptory sale and another downward step on the ladder of life - lower and lower still.

After his sale, Sheet Anchor was moved to a fourth-rate training stable of Jemmy Clever, being somewhat notorious for tricks and devices of a truly objectionable kind. "If we're to lose, we're paid for it: if to win, it must be made worth our while, so we go on as pleasant and safe as pausible."

Nearly every event at the provincial meetings to which Sheet Anchor was taken was previously arranged by 'standing in', dividing the stakes, and making the race a profitable certainty to all concerned. Finally, Sheet Anchor was made 'safe', not by the already known methods of poisoned water, administered drugs, purposely bruised shins or pricked frogs, but this time with a painted bit, another certainty of the turf. Sheet Anchor was not able to win and there were but few more downward steps for him. He was offered for public competition immediately after the race, and his new master was never known to lose at games of any sort and got up a raffle, as the only mean to make money of him after all. The winner, expressed a strong fear of having "gained a loss", and appealed to the assembled company for a suggestion as to "what he should do with him?" One said, "he should make a nice, quiet, easy-going cob, for an old gentleman, provided my ears and tail were cropped close". Another thought him "just the thing for a park hack", a third considered the cat'smeat barrow his proper destination and offered a premium for the prime cuts for a litter of thriving tortoise-shell kittens. A fourth, however, intimated that if he "was the unlucky gent of such a brute, he'd get out of'm by putting 'm up again at a lower figger". Sheet Anchor did not know how many times he was raffled for during the night by the jovial, rollicking party; but in the pale, slickly morning light, he was acknowledged property of an adventurous cabman.

The forgotten, worn-out race-horse has told his tale; but at the time of his bringing it to a close, little could be the conjecture that a far more pleasing scene might be truthfully added as 'The Finish': Leaving in the happy, contented sunset of life back in his birthplace, that would have been his wish.

\section{Comments}

The fictitious Sheet Anchor as above is not be confused with the real Sheet Anchor (GB, 1832), by Lottery out of Morgiana by Muley (Mortimer et al. 1978, Prior and Prior 1951). The chosen name, however, is certainly adopted with the determination to reflect on the situation of racing in the first half of the 19th century. At these times, in the early years of Queen Victoria (after 1837), racing in Great Britain is reported to have been at the lowest moral ebb of its history (Longrigg 1972).

Sheet Anchors' life as a foal was happy, but already his first education finds criticism. He gets acquainted with a DumbJockey, according to his feelings a pretty unpleasant experience, due to the natural sensitiveness of horses. Interestingly, only some few years later, de Montigny (1880) in France also considered this educational method as useless and even harmful. Moreover, he also refers to the psychological aspects of such a training in comparable words ("Je dois dire, en passant, que je considère toute espèce de Dumb Jockey comme une pratique tout à fait inutile et même fort nuisible, du fait que la pauvre bête se retrouve dans un état constant de surexcitation"). Both these opinions are in accordance with findings of research in ethology, behavior and learning theo- 
ries of today. The problem of irritability is also mentioned in Sheet Anchors' further training, a subject which is in agreement with the knowledge of our days: Most of what we do to train horses runs counter to their innate preferences (McGreevy and McLean 2007).

As a two-year-old in Newmarket, 'a dull, spiritless, ghostly pla$\mathrm{ce}^{\prime}$, Sheet Anchor also underwent the training-method of sweating, similar to the described practices of Scott in 1842 (Longrigg 1972). The latter gave his horses "a bursting fourmile spin in their clothes", but not long afterwards 'Druid' says: "Heavy-clothed sweats are fast going out of fashion". Speaking of The Flying Dutchman's preparation by Fobert in 1848/49, Corbet mentions: "Horses are no longer loaded with clothes, fagged and scraped, but they get the same amount of work without the unnecessary severity at once so general and so fatal" (Longrigg 1972). However, at this stage Sheet Anchor didn't suffer from the many possible medical problems of a racehorse as e.g. sore shins and tendonitis, still frequent causes for a headache for trainers and owners in our days.

The success in his first race was immediately followed by great interest on the part of the betting community, one of the main causes for problems and scandals of the Turf in those days. According to Longrigg (1972), at about 1804 the 'Legs' appeared. Since swindlers, and especially racecourse swind-lers, were called 'blacklegs', the Round Bettors came to be called 'Legs'. The activity of 'Round Betting' or 'Making a Book' meant that the legs took and layed bets, so that they could not lose regardless of the outcome of the race. Becau-

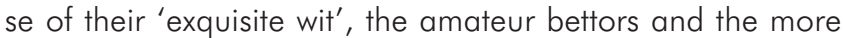
obtuse, who were no match for them, regarded them as swindlers and called them 'Legs' because they ran away when they couldn't or wouldn't pay (Sidney 2003). However, if a Leg laid heavily against a fancied horse, he climbed out of his risk by hedging, but this reduced the margin of profit. It was better to allow a clear favourite to be established by weight of public money, and then stop the horse winning. Any mean for stopping a horse was tried, and the town of Newmarket, was then (1818) infested by hordes of scoundrels of the most daring, villainous looks and characters. The methods of some Legs were as crooked as they could be, their principal technique being to bribe jockeys. What created the problem, was the scale of betting. As early as 1806, two full months before the St. Leger, 'there is little doubt that upwards of one million guineas had already been laid'. Laming a favourite therefore could make a fortune for a Leg overnight (Longrigg 1972).

Another well documented offence in the first half of the 19th century was the win of the 1844 Derby by the four-year-old 'Maccabeus', owned by Goodman Levi, who ran in the name of 'Running Rein' (Longrigg 1972, Mortimer et al. 1978, Byles 2011). Quite a few episodes in the story of Sheet Anchor seem to express hints to this fraud and remind of untenable circumstances.

In the preparation for his Derby, Sheet Anchor was carefully guarded that no one might injure him - again a reference to real happenings. This occurred to a horse (King Richard) of Crockford, said to have been the second most evil man on the 19th-century Turf. This colt was also fancied for the Derby, but his lad lamed his leg the night before. This shock killed
'Old Crocky' two days later on the morning of the Oaks, but his friends propped him in an armchair in the window of his club until after the filly-race, so that their bets were still on (Longrigg 1972).

The victory in the Derby was the culmination of Sheet Anchors' destiny, and it is simple worldly wisdom that zeniths always also are the beginning of the end. However, his fate wasn't just a normal decline, he much more became the subject of ruthless skulduggery in respect of 'making a book', of safe methods for increasing betting returns, respectively. However, such manipulations must have been usual practices, as in the first half of the 19th century trainers had the reputation of being 'ignorant cunning sots'. Only in 1864 was reported that "As a rule, a trainer is now a wellconducted, comparatively well-educated man". And in 1879, the opinon was "There can be no question that trainers and jockeys are far more honest in the present day than in the past, and that they are certainly quite as honest as employers". The main reason for this development most certainly was the appointment of the frugal and careful Admiral Rous as public handicapper 1855. At that time, his moral authority had not begun yet, but he brought to it a professionalism which was quite new. His whole attitude to the Turf was based on the inevitability of betting but with the necessity for moderate punting. When he emerged as "Dictator" in the early 1860s, it was seen that his attitude to racing was at once high-minded and practical. He recognized betting as an integral part of racing, necessary both to the interest of the public and the breeding and training bills of the great men. But he deplored heavy betting, as the inducement to fraud was too great. Racing should be conducted to earn the trust of men 'in the 10 pound way of business' (Longrigg 1972).

Beside the most favourable commitment of Rous, external influence also is said to have improved the integrity of racing and betting - above all the invention of the electric telegraph. It provided a rapid results service and reduced betting dishonesty. As newspapers became increasingly able to gain reports from the training areas by telegraph, the manipulating of horses in the betting market became less easy. Derby and St. Leger results were being transmitted to and from London as early as 1847 (Huggins 2000).

The 'roping' (stopping) of Sheet Anchor also led to the financial ruin of his owner and his sale followed in due course. However, financial problems also were the fate of the purchaser and his associates, one of the usual reasons for further sharp practices. The ruthless further management of Sheet Anchor finally caused his breakdown. The treatment of his ruptured tendon was bleeding and firing, and one certainly might expect that these methods shouldn't still be an accepted therapy in our days. However, firing still is practised and even tolerated, in spite of (written) provisions of the law of animal protection. In our days, both the poor standard of education of owners and trainers and the incompetence of governmental veterinary officers seem to be the main reasons for such a deplorable state of affairs.

At this stage, Sheet Anchor was sold once more and his new trainer Clever considered it worthwhile to use any tricks, drugs and maltreatments - a tradi-tional attitude which unfortunate- 
ly also still must be encountered nowadays, though with more sophisticated means and methods. However, this problem is recognized as the "Merry-Go-Round of Pain" by World Horse Welfare which is trying to call an end to it.

Finally, the worn-out racehorse was passed on to a cabman through a raffle. At this stage of his life, Sheet Anchors' wondered, whether a far more pleasing scene might be added as 'the finish'. His wish would have been to leave in the happiness of retirement. The fate of the retired horse (equus munere defunctus) is also an issue which has been an ongoing concomitant pheno-menon of horseracing. Already in the 'Love Books' of Ovid (liber secundus IXa), we notice the sentence: "The courser, freed from his stall, leapeth in the meadow" (mittitur in saltus carcere liber equus). And in our days, according to the staff and the correspondents of Blood-Horse Publications (2009), one of the most hotly debated issues in the Thoroughbred racing industry is the uncertain fate that awaits many racehorses when their careers are over.

\section{Conclusions}

Although the story of Sheet Anchor was published as a narrative only, the booklet is a plausible account of the situation in racing 150 years ago. It is proven true both by historical facts (Longrigg 1972, Mortimer et al. 1978) and also by experiences of our own with ongoing problems due to frailties of human nature. Without doubt, Mills painted gloomy pictures legitimately, easy to say retrospectively, of course. But how about today? Do we have to take contemporary commentaries and critical questions, which can be found in coarse numbers, seriously also? Just a single one of them may be mentioned: "Animal welfare as the salvation of horse racing?" (Miller 2014). Experienced veterinarians at least do perceive this chance and express their views also clearly, e.g. Stewart (2012): "Promotion of racehorse welfare is absolutely a key requirement for the future viability, even survival of the racing industry". Such a statement is much to our relief and also in accordance with the new report on equine welfare in the European Union (Owers and Tabram 2015). Moreover, all the enormous progress in veterinary medicine and genetics offer good possibilities for realizing such goals.

In the history of racing, betting obviously was a main reason for grievances. However, this risk is inherent to such activities and therefore has to be dealt with principally. As long as criminals see that the benefits of their crime out-weigh the costs such as the probability of apprehension, conviction, and potential punishment, they will grab the opportunities. According to the economist Gary Stanley Becker, fines therefore must be maximized (Forrest 2009).

In regard to welfare-issues in the context with the retirement of racehorses, some true progress happens in different places. There is a generally accepted understanding that the commitment to the care, health and well-being of a horse must come along with the thrill of owning it. At the very core of all this joy and pleasure is a deep responsibility and one can't have one without the other (Blood-Horse Publications 2009). Therefore, equine aftercare did become an increasingly important issue and should be looked after by every racing-organization.
According to Mitchell (2011), many problems are recognized, but todays society still is disheartened by the lack of attention to animal welfare by the racing industry itself. Beside this, the incompetence of some governmental authorities also hinders a rational approach to these matters.

Once again one wonders, whether external influence may bring decisive progress. Probably, technological advancements will bring us forward best again - the same as 150 years ago. Information technology (IT) already brought significant progress in different places, above all in regard to preventive medicine (Scollay 2009, Parkin 2015). But for the management of racing as an industry, the competence of experts in economy and business administration seems to be imperative. Therefore, IT-projects from independent institutions in these fields deserve consideration (Moser 2014, Pohl 2014). These means also allow to enhance effectively the badly wanted education of the people in charge (Palmer et al. 2015).

\section{References}

Byles T. (2011) In Search Of Running Rein, The Amazing Fraud Of The 1844 Derby. Apex Publishing Ltd., Clacton on Sea, UK

Forrest D. (2009) Risks To The Integrity Of Sport From Betting Corruption; EPMA Conference "The Pari Mutuel model for the funding of racing and sport", Brussels. 22.1

Huggins M. (2000) Flat Racing and British Society 1790-1914, A social and economic history. Frank Cass, London

Longrigg R. (1972) The History of Horse Racing. Macmillan London Ltd.

McGreevy P. D., McLean A. N. (2007) The roles of learning theory and ethology in equitation. J. Vet. Behav. 2, 108-118

Miller J. (2014) Animal welfare as the salvation of horse racing? Special to The Courier-Journal, September 13

Mills J. (1865) The Life of a Racehorse; Ward, Lock and Taylor, London

Mitchell E. (2011) Strawbridge Urges Strong Medication Reform. Blood Horse, 10.30

de Montigny M. le Comte (1880) Manuel des piqueurs, coches, grooms et palefreniers à l'usage des écoles de dressage \& d'équitation de France. Cinquième Edition 1880, Augmentée d'une huitième partie: De l'élevage et de l'entrainement des chevaux de course et de chasse, d'après Digby Collins. Librairie militaire de J.Dumaine, Paris

Mortimer R., Onslow R., Willett P. (1978) Biographical Encyclopedia of British Flat Racing. MacDonald and Jane's Ltd., London, 213

Moser G. (2014) Konzept für Innovationen am Beispiel des Horse Racing Tools. Masterarbeit Advanced Studies Business Communications, Fachhochschule für Wirtschaft, Zürich

Ovid (Publius Ovidius Naso, 43 BC-AD 17/18) Love Books, translated by J. Lewis, 1930

Owers R., Tabram H. (2015) Groundbreaking new report on equine welfare in the European Union (EU). Equine Vet. Educ. 27, 281-282

Palmer S., Arthur R., Benben A. (2015) The Importance of Continuing Education. Sixth Welfare and Safety Summit, Grayson-Jockey Club Research Foundation, Keeneland, 8. July

Parkin T. (2015) Equine Injury Database - Models, Risk Factors and Prediction. Sixth Welfare and Safety Summit, Grayson-Jockey Club Research Foundation, Keeneland, 8. July

Pohl K. I. (2014) Strukturelle Anforderungen an eine Datenbank über Verletzungen bei Rennpferden. Bachelorarbeit Studiengang Pferdewirtschaft, Fakultät für Agrarwirtschaft, Volkswirtschaft und Management, Hochschule für Wirtschaft und Umwelt NürtingenGeislingen

Prior C. M., Prior F. M. (1951) Stud-Book Lore. Prior Bletchley, UK, 212-214 
Scollay M. (2009) The Racetrack, A Changing Perspective; Equine Disease Quart. 18, 4

Sidney C. (2003) The Art of Legging, The History Theory And Practice Of Book-making On The English Turf. Third edition. Rotex London

Staff and Correspondents of Blood-Horse Publications (2009) Second-Chance Horses. Eclipse Press, Blood-Horse publications and The Keeneland Association, Lexington, KY

Stewart B. D. (2012) IGSRV (International Group of Specialist Racing Veterinarians) Newsletter 15

\section{Zusammenfassung}

\section{Das Leben eines Rennpferdes - vor 150 Jahren und heute}

Mit 'The Life Of A Racehorse' ist ein Büchlein betitelt, das 1865 in London erschien (John Mills). In 21 Kapiteln auf 112 Seiten umfasst es das Schicksal des fiktiven Rennpferdes "Sheet Anchor". Seine Erinnerungen an ein Leben voll sorgenvoller Veränderungen beginnen mit der ersten Ausbildung und dem Training, wo ein Pferd wegen seiner natürlichen Feinfühligkeit weder getadelt noch bestraft werden sollte. Er entwickelte sich nichtsdestoweniger zu einem erfolgreichen Zweiiährigen und zum Sieger im Derby. Sein Erfolg weckte das Interesse der Wetter und das Schicksal von "Sheet Anchor" nahm einen anderen Lauf. Er wurde das Opfer von sicheren Methoden für die Steigerung von Wettgewinnen, indem nun gegen ihn gewettet wurde. Er erlitt Niederlagen durch skrupellose Taktiken, brach nieder, wurde gedopt und misshandelt, wurde mehrere Male verkauft und endete nach einer Lotterie im Besitz eines Droschkenkutschers. An dieser Stelle wunderte er sich, ob sein Abschied zurück an seinem Geburtsort ein viel gefälligeres Ende wäre. Obwohl die Geschichte von "Sheet Anchor" als eine Novelle präsentiert wurde, reflektieren die düsteren Bilder die Situation des Rennsports in der ersten Hälfte des 19. Jahrhunderts getreu. Es wird berichtet, dass der Rennsport in Großbritannien zu dieser Zeit auf dem tiefsten moralischen Stand seiner Geschichte war. Die beschriebenen Methoden der Ausbildung und des Trainings werden auch in anderen Publikationen kritisiert und können sogar heute noch angetroffen werden. Bedaverlicherweise muss gleiches auch bezüglich gewisser medizinischer Behandlungen des Rennpferdes gesagt werden. In der Geschichte des Rennsports war das Wetten offensichtlich ein Hauptgrund für Missstände, und mit diesen Risiken (oder menschlichen Schwächen) müssen wir uns auch in unserer Gesellschaft noch beschäftigen. In Bezug auf Belange des Wohlbefindens von pensionierten Rennpferden erfolgte glükklicherweise an verschiedenen Orten Fortschritt. Man ist sich heute allgemein einig, dass die Verpflichtung für die Pflege und das Wohlbefinden eines Pferdes mit der Begeisterung seines Besitzes einher gehen muss. Damit übereinstimmend wird die Förderung des Wohlergehens der Rennpferde als eine Schlüssel-Voraussetzung für die zukünftige Lebensfähigkeit der Renn-Industrie erachtet.

Schlüsselwörter: Pferd / Rennsport / Geschichte / Ausbildung / Training / Wettbetrieb / Verletzungen / Wohlbefinden 